THE GLORIES OF IMMIGRATION:

HOW FOOTBALL WINS SHAPE OPINION ON IMMIGRATION *

\author{
Ignacio Lago \\ Universitat Pompeu Fabra \\ Department of Political and Social Sciences \\ Universitat Pompeu Fabra \\ Ramon Trias Fargas 25-27 \\ 08005 \\ Barcelona, Spain \\ E-mail: ignacio.lago@upf.edu
}

\title{
Carlos Lago-Peñas
}

University of Vigo \& Governance and Economics research Network (GEN)

Faculty of Education and Sport Sciences

University of Vigo

Campus Universitario $\mathrm{s} / \mathrm{n}$

36005

Pontevedra - Spain

E-mail: clagop@uvigo.es

\begin{abstract}
While there is a great deal of anecdotal evidence on the impact of football wins on attitudes toward immigrants and immigration, there is relatively little hard empirical evidence. We expect that football stimulates more positive attitudes towards immigrants when it highlights benefits rather than costs of immigration. We rely on individual-level data from the eight rounds of the European Social Survey (2002-2016) in Spain and aggregated data from the Spanish football league, La Liga, to test the hypothesis that the more expatriate players in the squid of the club winning the corresponding edition of the Spanish La Liga, the more favorable the views toward immigrants in the club's region in that year. The main finding is that, irrespective of how the attitudes toward immigrants and immigration are measured, respondents have more positive views the more foreign players the winning club has.
\end{abstract}

Key words: Attitudes, European Social Survey, Football, Immigration.

*The authors acknowledge support from the Spanish Minister of Science, Innovation and Universities (Grant numbers AEI/FEDER CSO2017-85024-C2-1-P and DEP201675785-R) and the Catalan Institution for Research and Advanced Studies (ICREA). 


\section{Introduction}

Football and immigration are fully intertwined. One popular but untested suspicion is that football wins affect popular support for immigration. The following two examples from Men's World Cup are enlightening. Some days after the France's 1998 triumph, The New Yorker claimed that 'traditionally, it's difficult for an immigrant or an outsider in France to achieve institutional acceptance, but now, with the victory, the ethnic members of the World Cup team had been fully integrated into the French self-image. Even though the World Cup team is multiracial, Le Pen and the racist National Front have already claimed the victory for themselves.' ${ }^{1}$ Similarly, twenty years later, for the Washington Post "in an era of increasing nationalism and fortified borders, France's 2018 World Cup success has allowed for the creation of a more optimistic narrative of the value of immigration.' ${ }^{2}$

This conventional wisdom about the relationship between football and support for immigration hinges on the interaction between the saliency of football and the increasing number of football expatriate players (i.e., players having grown up outside of the national association of their employer club and having gone abroad for footballrelated reasons according to the definition provided by Poli et al., 2018: 4), On the one hand, according to a survey conducted by Nielsen Sports (2018) in 30 countries across the Americas, Europe, the Middle East and Asia in 2017, the 43 percent of respondents were "interested" or "very interested" in football. The popularity of football, however, differs greatly across countries. Using again the data from Nielsen Sports, while in the United Arab Emirates the 80 percent of the population is interested in football, in the U.S. the percentage is substantially lower, the 32 percent. On the other hand, since the Bosman transfer ruling in the 1990s, a sectorial liberalization shock on football labor markets that made quotas on the number of foreigners playing for a club illegal (Binder and Findley, 2012), the proportion of expatriates players have gradually increased. During the last decade, the proportion of expatriates in the leagues studied has increased from 34.7 percent to a record level of 41.5 percent in 2018 (Poli et al., 2017).

Our aim is to ascertain to what extent football affect attitudes toward immigrants and immigration. While there is a great deal of anecdotal evidence on the impact of football wins on attitudes toward immigrants and immigration, there is relatively little

\footnotetext{
${ }^{1}$ https://www.newyorker.com/magazine/1998/07/27/the-sporting-scene-6

${ }^{2}$ https://www.washingtonpost.com/news/made-by-history/wp/2018/07/20/stop-calling-the-french-worldcup-victory-an-immigrant-win/?utm term $=.346 \mathrm{~b} 56 \mathrm{fbf59 \textrm {e }}$
} 
hard empirical evidence. We expect that football stimulates more positive attitudes towards immigrants when it highlights benefits rather than costs of immigration. When football clubs or national teams win, immigration is framed in positive terms as expatriate players or players of immigrant origin are essential to the success. We rely on data from Spain to show that the more expatriate players in the squid of the club winning the corresponding edition of the Spanish La Liga, the more favorable the views toward immigrants in the club's region in that year. As the cross-national evidence may be not quite as reliable as we would wish due to the varying popularity of football across countries (i.e., a crucial parameter affecting the effect of framing, and the different origin, number and quality of expatriate players (Poli et al., 2017), we examine the relationship between football and opinion on immigration within a country. The individual-level data come from the eight rounds of the European Social Survey (20022016).

\section{Arguments}

Individuals' opinions on immigration have been traditionally explained from the political economy and the sociopsychological traditions. While the former is focused on native-born citizens' individual self-interest, in particular the distributional consequences of immigration, the later emphasizes the role of group-related attitudes and symbols in shaping immigration attitudes. The accumulated evidence weighs against the idea of that self-interest concerns about labor market competition are a driver of opinions on immigration. On the contrary, perceptions about immigration's impact on salient social groups, mainly those based on nationality and those based on ethnicity, are powerful correlates of immigration attitudes (Hainmueller and Hopkins, 2014).

More recently, individuals' attitudes toward immigration have been shown to depend upon frames and symbols salient in discussions of immigration. Roughly speaking, framing refers to the process by which people develop a particular conceptualization of an issue or reorient their thinking about an issue Specifically, an attitude toward an object, in this case immigration, is the weighted sum of the evaluation of the object on an specific attribute or dimension and the salience weight associated with that attribute (Chong and Druckman, 2007: 104-105).

Elite rhetoric and information environment play central roles in explaining of immigration attitudes, specially their dynamics (Hainmuller and Hopkins, 2014: 244). 
Parties (and candidates) and the mass media deliberately create immigration framings impacting individual's attitudes toward immigration. First, using survey experiments during the 2008 Iowa Caucus campaign, Knoll and Redlawsk (2011) found that framing labels matter, but only Republican partisans for whom the immigration issue is important. More recently, Jones and Martin (2017) claim that campaign prioritization of immigration has a directional cue: candidates with more extreme immigration positions are more likely to prioritize the issue of immigration in their campaigns. These cues are significantly related to individuals' policy preferences on the immigration issue. Republican cues move attitudes toward the restrictionist end of the spectrum, but only in geographical locations associated with high rates of Hispanics, foreign-born individuals, and undocumented immigrants.

Second, media coverage is an important explanation for immigration attitudinal change. Brader et al. (2008) use experimental data to show that, while news emphasizing the costs of immigration boosts the perception that immigration is harmful, ethnic cues strongly condition emotional reactions to this news. Stigmatized outgroups, in this case Latino immigrants, trigger negative emotions when costs are emphasized. Dunaway et al. (2010) found that amplified media coverage of immigration leads to a heightened perception among the public that immigration is an important policy concern facing the nation. Moreover, we find regional variation in the amount of media coverage devoted to immigration. The volume of immigration coverage in border states is significantly greater than the amount of immigration coverage in nonborder states. By relying on survey experiments, Merolla et al. (2013) found strong framing effects with respect to how immigration policies are described in the news: when frames highlight the negative externalities of immigration, restrictionist opinion increases, while when frames are focused on less-restrictionist policy options, restrictionist preference abated. Similarly, Abrajano et al. (2017) found that immigration frames have a substantial impact on partisanship. Negative frames of immigration in the New York Times between 1980 and 2011 lead to greater white ties to the Republican Party and a reduced likelihood of identifying as Democrats.

In contrast with the strategic or deliberate immigration emphasis by candidates and the mass media, we contend that football can create unintended immigration frames significantly affecting opinions on immigration. We begin with the assumption that when an issue is framed in positive terms, the public may consequently take a favorable view of the group referenced by the frame. As we already know, the number of 
expatriate players in football club squads has substantially increased in the last years. On May 1 2017, 12,051 expatriate footballers were recorded in the 2,120 clubs competing in 137 leagues of 93 national associations worldwide. (Poli et al., 2017). In Spain, on the 1st of October 2018, expatriates accounted for the 38.6 percent of the squads in La Liga, a 38.1 percent greater than in 2009 (Poli et al., 2018). The available evidence shows that having more foreign football players favors the performance of clubs at the international level (Royuela and Gásquez, 2018).

As a result, when football clubs or national teams win, immigration is framed in positive terms as expatriate players or players of immigrant origin are essential to the success. The 'threat' frame of immigration in economic, social and security aspects is replaced with an emphasis on the positive effect of immigration for the economy and the creation of a more open and cosmopolitan society. Using the USA Today's words after the France's 2018 World Cup success, "the art of being successful at a World Cup is about collecting multiple identities and getting them to work together as a collective and cohesive group, regardless of where they are from." 3 At the club level, for instance, when Real Madrid won their third UEFA Champions League in a row in 2018, only three players in the starting line-up were born in Spain.

However, not all frames are readily accepted by everyone who encounters them (Knoll and Redlawsk, 2011). Those who care more about an issue are more affected by frames about it, as their mix of considerations on the issue is deeper (Zaller, 1992). Football is a very salient issue for most individuals in most countries in the world and therefore we should expect that all social groups within will be affected by frames about it. According to Nielsen Sports (2018), the 70 percent of individuals in Spain in 2017 were interested in football. In other words, frames about football are not cross-cutting across social groups.

As attitudes toward immigration are the combination of the positive evaluations created by the framing and the salience weight attributed to immigration, we expect that the effect of the number of expatriate players in football club squads is contingent on winning:

$H_{1}$. Conditioned on winning, the number of expatriate or immigrant-origin players in a football club squad will be associated with better opinions on immigration.

\footnotetext{
${ }^{3}$ https://eu.usatoday.com/story/sports/columnist/martin-rogers/2018/07/10/world-cup-immigration-france-
} belgium-england/771277002/ 


\section{Data and Methods}

The relationship between football and opinion on immigration is examined within Spain. Apart from the availability of data capturing attitudes towards immigrants and immigration, we focus on Spain due to the high level of immigrants in the country, the substantial number of expatriate football players and the saliency of football. First, according to Eurostat (https://ec.europa.eu/eurostat/statisticsexplained/pdfscache/1275.pdf), Spain reported the third largest total number of immigrants (414.7 thousand) of the EU Member States in 2016. Relative to the size of the resident population, Spain had 8.9 immigrants per 1,000 persons in 2016, while the average of the EU Member States was 4.6. Second, expatriate players have a crucial role in the Spanish La Liga. For instance, in the 2015/16 season, the percentage of minutes played by foreign players reached the 41.8 according to www.transfermarkt.com. Finally, football is very popular in Spain. In a face-to-face survey $(\mathrm{N}=2,486)$ conducted by the Centro de Investigaciones Sociológicas in Spain in June 2014, the 67.4 percent of respondents felt close of a football club (the 77.9 percent of men and the 57.5 percent of women). ${ }^{4}$ As our empirical analysis looks at variations in opinion on immigration across regions, we control for the popularity of football.

The individual-level data come from the European Social Survey (ESS). The data from the eight surveys conducted in Spain in the 2002-2016 period have been pooled to increase the sample size and obtain more robust estimates. The number of respondents in the samples ranges from 1,663 in the second round to 2,576 in the fourth. The total number of respondent is 15,501 . In the ESS, data have to be collected via faceto-face interviews. Samples are representative of all persons aged 15 and over (no upper age limit) resident within private households in each country, regardless of their nationality, citizenship or language. Individuals are selected by strict random probability methods. We have matched every round of the ESS with the edition of La Liga finished before starting the fieldwork of the respective round of the ESS. More specifically, all the editions of La Liga finished in May, while the fieldwork of the ESS was as follows: ESS round 1, November 2002-February 2003; ESS round 2, September 2004-January 2005; ESS round 3, October 2006-February 2007; ESS round 4,

\footnotetext{
${ }^{4}$ The specific question in the survey is the following: "Independently of your interest in professional football, do you feel close to or have sympathy for any club or clubs or in this sport? (http://www.cis.es/cis/opencm/EN/2 bancodatos/estudios/ver.jsp? estudio=14090\&cuestionario $=16891$ \& muestra $=22448$ ).
} 
September-December 2008; ESS round 5, April-July 2011; ESS round 6, January-May 2013; ESS round 7, January-April 2015; and ESS round 8, February-May 2017.

Post-stratification weights have been used. They have been obtained by adjusting the design weights in such a way that they will replicate the distribution of the cross-classification of age group, gender, and education in the population and the marginal distribution for region in the population (see https://www.europeansocialsurvey.org for more details).

As the variables have been measured exactly in the same way in the eight rounds of the ESS and the methodological design of all surveys is similar, the ex-post harmonization of data is not an issue and the data are perfectly comparable (Granda et al., 2010).

The dependent variable, the attitudes toward immigrants and immigration, has been operationalized in four different ways to show the robustness of the results:

- The respondents' opinion about whether Country's cultural life is undermined or enriched by immigrants using an 11-point scale going ranging from 0 (cultural life undermined) to 10 (cultural life enriched).

- The respondents' opinion about whether immigration is bad or good for Country's economy using an 11-point scale going ranging from 0 (bad for the economy) to 10 (good for the economy).

- The respondents' opinion about whether Spain should allow many/few immigrants from poorer countries outside Europe: allow many to come and live here (4), allow some (3), allow a few (2) or allow none (1).

- The respondents' opinion about whether Spain should allow many/few immigrants of different racelethnic group from majority: allow many to come and live here (4), allow some (3), allow a few (2) or allow none (1).

The key independent variables are two:

- Winner, coded one if a team from the region has won the corresponding league when the ESS round was conducted, 0 otherwise. If there are no clubs from a region playing La Liga, the value is 0 . The source is La Liga (https://www.laliga.es/).

- The percentage of minutes played by foreign players. We have only considered the best qualified club in the region in every league/round of the ESS. If there are no clubs from a region playing La Liga, the value is 0 . When using the value for the best qualified team in the region, the variables goes from 0 to 74.6 
percent (the Real Madrid in the eighth round of the ESS, the 2015/6 league). If we focus on the eight winners of the corresponding La Liga, the variable goes from 30.1 percent (the Valencia C.F. in the 2003/4 league) to 64.0 (the F.C. Barcelona in the 2005/6 league). The distribution of the variable is displayed in Figure $1 .{ }^{5}$ The source is Transfermarkt

(https://www.transfermarkt.com/laliga/legionaereeinsaetze/wettbewerb/ES1/plus/?optio

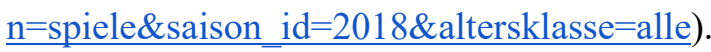

Figure 1: \% Minutes played by foreign players

(best qualified club in the region)*

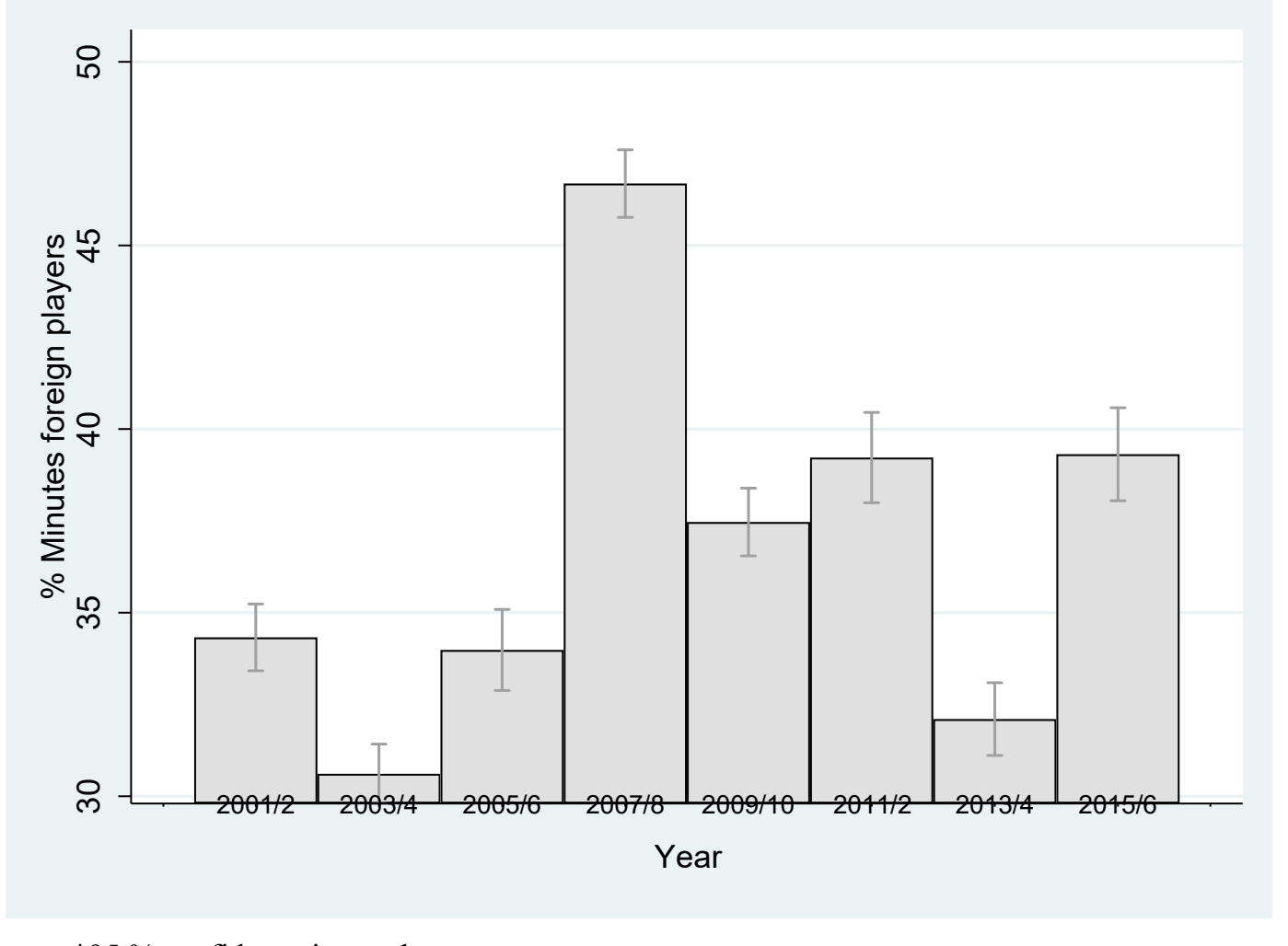

$* 95 \%$ confidence intervals

We have included the conventional attitudinal and nonattitudinal controls capturing the political economy and the sociopsychological traditions and using the preferred indicators for accentuating the differences between contrasting groups (Ceohanu and Escadell, 2010: 317-321): age (in years), gender (1, female; 0, male),

\footnotetext{
${ }^{5}$ The results of our analyses are qualitatively the same wen using the average of all clubs from a region in each year. The variable goes from 0 to 58 percent (in Andalucia in the five round of the ESS, the 2009-10 league).
} 
education (less than lower secondary, lower secondary completed, upper secondary completed, post-secondary and tertiary completed), social stratification (1, unemployed, 0 , otherwise) income (in deciles), and the identification with the European Union (whether the European unification go further, 10, or gone too far, 0). Finally, given that there are no questions in the survey capturing perception about the size of the immigrant population, we control for the objective size (i.e. the percentage) of the immigration population in the region (the number of foreign population divided by the total population). The source is the Spanish Statistical Office (http://www.ine.es/jaxi/Tabla.htm?path=/t20/e245/p08/10/\&file=02005.px\&L=0).

The model we estimate is the following:

$$
\begin{aligned}
& \text { Attitudes }_{i}=\beta_{0}+\beta_{1} \text { Age }_{i}+\beta_{2} \text { Female }_{i}+\beta_{3} \text { Education }_{i}+\beta_{4} \text { Unemployed }_{i}+ \\
& \beta_{5} \text { Income }_{i}+\beta_{6} \text { EUunification }_{i}+\beta_{7} \% \text { Foreigners }_{i r}+\beta_{8} \% \text { ForeignPlayers }_{i r}+ \\
& \beta_{9} \% \text { LeagueWinner }_{i r}+\beta_{10} \% \text { ForeignPlayers }^{*} \text { LeagueWinner }_{i r}
\end{aligned}
$$

Given that the dependent variable is continuous when using Country's cultural life and Country's Economy and ordinal when using allow many/few immigrants from poorer countries outside Europe and allow many/few immigrants of different race/ethnic group from majority, linear (OLS) and ordered probit (which does not assume the Independence of Irrelevant Alternatives) regressions have been run. Finally, although the structure of the data is hierarchical (by individual and regions), we have decided not to run a multilevel model. According to Bryan and Jenkins (2016: 19-20) based on Monte Carlo simulations, multilevel models require 25 countries (regions in our case) for linear models and 30 countries for logit (probit here) at the very minimum, and most likely more for models with a specification other than a relatively basic one. As they argue, estimates of country-level fixed parameters (region level in our analyses) are likely to be estimated imprecisely and this will not be adequately reflected in test statistics reported by commonly used software. All standard errors are clustered by region to account for non-independence in the data structure.

\section{Results}

In Table 2 we compare how the attitudes towards immigrants differ depending on where respondents in the ESS live. Three different groups of individuals have been distinguished: (1) those who lived in Catalonia, Madrid and Valencia in the years when 
a club from the region won the corresponding La Liga (F.C. Barcelona in 2006, 2010 and 2016; Real Madrid C.F. in 2008, 2012; Valencia C.F in 2002 and 2004, and Atlético de Madrid in 2014); (2) those who lived in Catalonia, Madrid and Valencia in the year when a club from the region did not win the corresponding La Liga; and (3) those living in the remaining fourteen regions. According to our argument, we should expect that the first group should have better attitudes toward immigrants than the third one. The expectation is strongly supported. The mean of the four variables is greater for the former than for the latter: the gap is 0.33 when asking about how immigration affects the country's cultural life, 0.39 when asking about the consequences for the country's economy, 0.09 when asking about the arrival of immigrants from poorer countries outside Europe, and 0.08 when asking about the arrival of immigrants of different race/ethnic group from majority. All the differences between the two groups of respondents are statistically significant at the 1 percent level (the $t$ statistics are 6.26. $6.35,4.59$ and 3.67 , respectively).

Table 1: Attitudes toward immigrants

\begin{tabular}{|c|c|c|c|}
\hline & $\begin{array}{l}\text { Cat, Mad and Val } \\
\text { in winning years }\end{array}$ & $\begin{array}{c}\text { Cat, Mad and Val in } \\
\text { not winning years }\end{array}$ & Remaining regions \\
\hline \multicolumn{4}{|c|}{ Country's cultural life $(0-10)$} \\
\hline Observations & 1,858 & 3,757 & 9,058 \\
\hline Mean & 6.30 & 6.03 & 5.93 \\
\hline Std. Dev. & 2.31 & 2.40 & 2.34 \\
\hline \multicolumn{4}{|c|}{ Country's economy $(0-10)$} \\
\hline Observations & 1,848 & 3.754 & 9,140 \\
\hline Mean & 5.56 & 5.49 & 5.17 \\
\hline Std. Dev. & 2.37 & 2.32 & 2.36 \\
\hline \multicolumn{4}{|c|}{ Immigrants outside Europe (1-4) } \\
\hline Observations & 1,840 & 3,710 & 9,149 \\
\hline Mean & 2.66 & 2.66 & 2.57 \\
\hline Std. Dev. & 0.90 & 0.94 & 0.93 \\
\hline \multicolumn{4}{|c|}{ Immigrants different group (1-4) } \\
\hline Observations & 1,803 & 3,706 & 9,133 \\
\hline Mean & 2.64 & 2.66 & 2.56 \\
\hline Std. Dev. & 0.93 & 0.94 & 0.92 \\
\hline
\end{tabular}

As there are multiple micro-level determinants of attitudes toward immigrants and immigration (Ceobanu and Escandell, 2010; Hainmueller and Hopkins, 2014), we examine in Table 2 the relationship between football and public views toward immigrants and immigration though linear and ordinal regressions in which the controls 
are included. The main finding is that, irrespective of how the attitudes toward immigrants and immigration are measured, respondents have more positive views toward immigrants and immigration the more foreign players the winning club has. The interaction term (Foreign players*League winner) is positive and statistically significant at the 0.05 percent level in the two OLS models and at the 0.01 percent level in the two probit models. Most of the controls behave as expected. Education and the identification with the European Union have the most robust effects across models. Both have a positive and statistically significant impact on attitudes towards immigrants in the four models. Similarly, gender, unemployment, income and the percentage of foreigners in the region have a consistent effect in the four models, but they are only statistically significant in three or less models. Finally, age has a negative and statistically significant in three of the models, but positive in the first one. In sum, a higher educational level and positive views about the European unification deter the expression of anti-immigration attitudes, while older respondents, men and those from lower socioeconomic strata or in vulnerable situation in regions with a lower immigrant population are more likely to hold negative attitudes. 
Table 2: The determinants of attitudes toward immigrants

\begin{tabular}{|c|c|c|c|c|}
\hline & \multicolumn{2}{|c|}{ OLS models } & \multicolumn{2}{|c|}{ Ordinal probit models } \\
\hline & Economy & Culture & Outside Europe & Allow immigrants \\
\hline Age & $\begin{array}{c}0.001 \\
(0.002)\end{array}$ & $\begin{array}{l}-0.005^{*} \\
(0.002)\end{array}$ & $\begin{array}{c}-0.005 * * \\
(0.002)\end{array}$ & $\begin{array}{c}-0.004 * * \\
(0.001)\end{array}$ \\
\hline Female & $\begin{array}{c}-0.395^{* *} \\
(0.059)\end{array}$ & $\begin{array}{c}-0.115^{*} \\
(0.045)\end{array}$ & $\begin{array}{l}-0.059 \\
(0.036)\end{array}$ & $\begin{array}{l}-0.033 \\
(0.026)\end{array}$ \\
\hline Education (ref. less than lower secondary) & & & & \\
\hline Lower secondary completed & $\begin{array}{c}0.278^{*} \\
(0.105)\end{array}$ & $\begin{array}{c}0.307 * * \\
(0.075)\end{array}$ & $\begin{array}{c}0.158^{* *} \\
(0.051)\end{array}$ & $\begin{array}{c}0.206^{* *} \\
(0.052)\end{array}$ \\
\hline Upper secondary completed & $\begin{array}{c}0.794 * * \\
(0.119)\end{array}$ & $\begin{array}{c}0.922 * * \\
(0.135)\end{array}$ & $\begin{array}{c}0.273 * * \\
(0.071)\end{array}$ & $\begin{array}{c}0.368 * * \\
(0.069)\end{array}$ \\
\hline Post-secondary & $\begin{array}{l}0.272 * \\
(0.114)\end{array}$ & $\begin{array}{c}0.476 * * \\
(0.145)\end{array}$ & $\begin{array}{l}0.123^{*} \\
(0.058)\end{array}$ & $\begin{array}{l}0.239 * \\
(0.069)\end{array}$ \\
\hline Tertiary completed & $\begin{array}{l}1.098 * * \\
(0.095)\end{array}$ & $\begin{array}{c}1.215 * * \\
(0169)\end{array}$ & $\begin{array}{c}0.538 * * \\
(0.061)\end{array}$ & $\begin{array}{c}0.587 * * \\
(0.067)\end{array}$ \\
\hline Unemployed & $\begin{array}{c}-0.277^{*} \\
(0.099)\end{array}$ & $\begin{array}{c}-0.072 \\
(0.111)\end{array}$ & $\begin{array}{c}-0.078 \\
(0.068)\end{array}$ & $\begin{array}{c}-0.116^{*} \\
(0.056)\end{array}$ \\
\hline Income & $\begin{array}{l}0.027^{*} \\
(0.010)\end{array}$ & $\begin{array}{c}0.022 * * \\
(0.006)\end{array}$ & $\begin{array}{c}0.002 \\
(0.007)\end{array}$ & $\begin{array}{c}0.003 \\
(0.007)\end{array}$ \\
\hline European unification & $\begin{array}{c}0.295 * * \\
(0.016)\end{array}$ & $\begin{array}{c}0.305 * * \\
(0.015)\end{array}$ & $\begin{array}{c}0.152 * * \\
(0.010)\end{array}$ & $\begin{array}{c}0.150 * * \\
(0.008)\end{array}$ \\
\hline$\%$ of Foreigners & $\begin{array}{l}-0.006 \\
(0.033)\end{array}$ & $\begin{array}{l}-0.058 \\
(0.051)\end{array}$ & $\begin{array}{c}-0.120 * * \\
(0.024)\end{array}$ & $\begin{array}{c}-0.093 * * \\
(0.026)\end{array}$ \\
\hline$\%$ of Foreign players & $\begin{array}{c}0.001 \\
(0.002)\end{array}$ & $\begin{array}{c}0.000 \\
(0.006)\end{array}$ & $\begin{array}{c}0.000 \\
(0.002)\end{array}$ & $\begin{array}{l}-0.001 \\
(0.002)\end{array}$ \\
\hline League winner & $\begin{array}{c}-0.903^{* *} \\
(0.309)\end{array}$ & $\begin{array}{c}-1.326^{*} \\
(0.537)\end{array}$ & $\begin{array}{c}-0.946^{* *} \\
(0.238)\end{array}$ & $\begin{array}{c}-0.885^{* *} \\
(0.278)\end{array}$ \\
\hline Foreign players $*$ League winner & $\begin{array}{l}0.015 * \\
(0.005)\end{array}$ & $\begin{array}{l}0.025^{*} \\
(0.009)\end{array}$ & $\begin{array}{c}0.018 * * \\
(0.005)\end{array}$ & $\begin{array}{c}0.017 * * \\
(0.005)\end{array}$ \\
\hline Constant & $\begin{array}{c}3.633^{* *} \\
(0.334)\end{array}$ & $\begin{array}{c}4.449 * * \\
(0.265)\end{array}$ & & \\
\hline Cut 1 & & & $\begin{array}{l}-1.187 \\
(0.179)\end{array}$ & $\begin{array}{l}-1.078 \\
(0.132)\end{array}$ \\
\hline Cut 2 & & & $\begin{array}{c}-0.006 \\
(0.180)\end{array}$ & $\begin{array}{c}-0.088 \\
(0.150)\end{array}$ \\
\hline Cut 3 & & & $\begin{array}{c}1.029 \\
(0,162)\end{array}$ & $\begin{array}{c}1.172 \\
(0,134)\end{array}$ \\
\hline $\mathrm{R}^{2} /$ Pseudo $\mathrm{R}^{2}$ & 0.172 & 0.183 & 0.083 & 0.084 \\
\hline $\mathrm{N}$ & 5,488 & 5,486 & 5,377 & 5,423 \\
\hline \# of Clusters & 17 & 17 & 17 & 17 \\
\hline
\end{tabular}

Fixed-effects included. Standard errors in parentheses.

$* * \mathrm{p}<0.01 ; *_{\mathrm{p}}<0.05$.

As interaction effects are not apparent using the information provide in Table 2 (Brambor et al., 2006), the effect of winning the corresponding La Liga across different percentages of minutes played by foreign players of the best club in the region in the OLS models is graphically illustrated in Figure 1. The slope is flat when the club has not won La Liga, but positive for successful clubs. In those regions with clubs winning La Liga, the opinion about how immigration affects the Country's cultural life and the 
Country's economy is 0.99 and 0.62 points greater respectively when moving from the 30 to the 70 percent of minutes played by foreign players.

Figure 2: The impact of football on attitudes toward immigrants
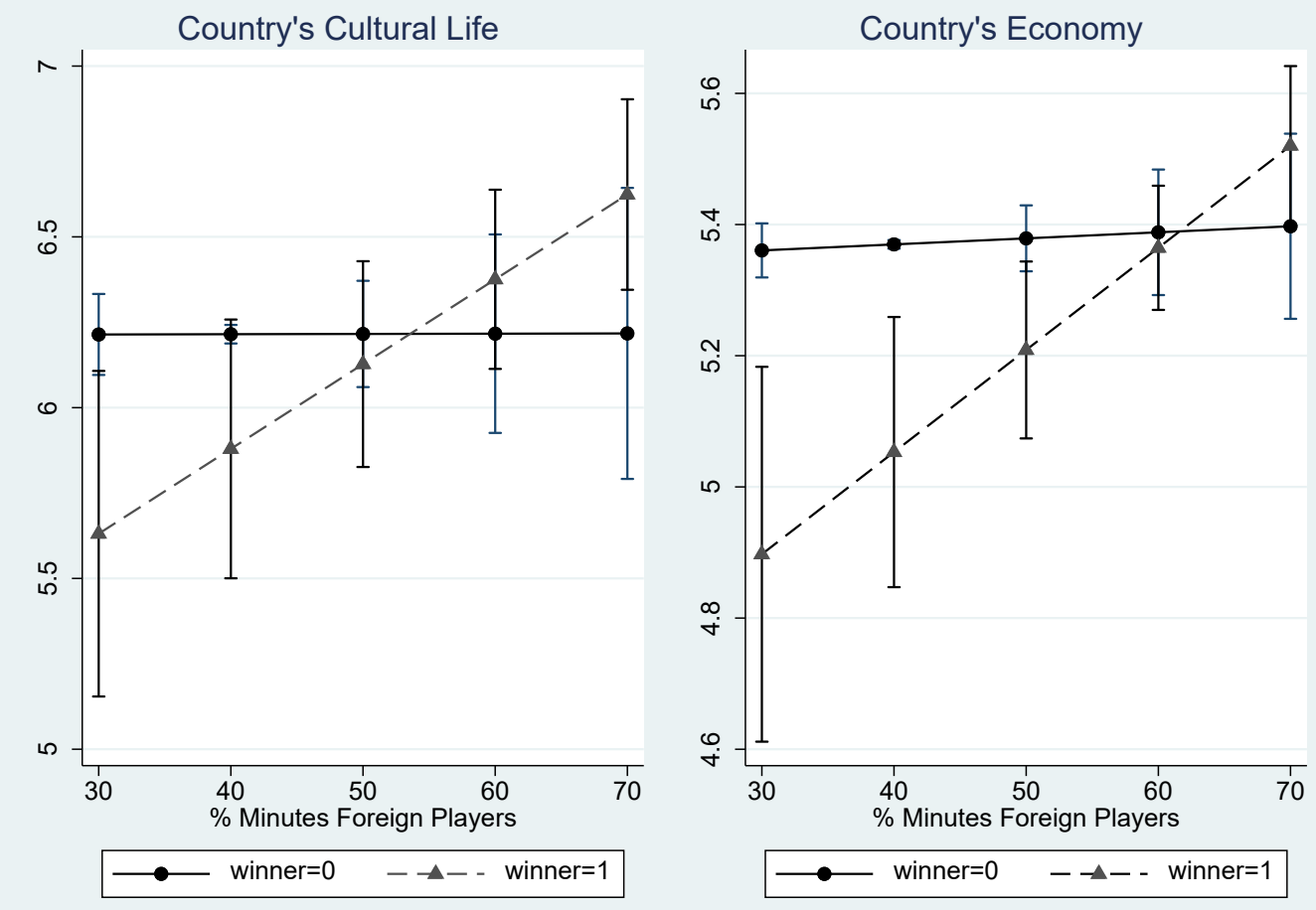

Based on the results of our ordinal regressions, in Table 3 we have calculated the probability of thinking that many immigrants from poorer countries outside Europe and of different race/ethnic group from majority should come and live in Spain. While the probabilities do not substantially change depending on the relevance of foreign players when a club from the region has not won La Liga, respondents have much more positive views toward immigrants and immigration the more foreign players the winning club has. When moving from the 30 to the 70 percent of minutes played by foreign players, the probabilities of allowing many immigrants is more than double. 
Table 3: Predicted probabilities

\begin{tabular}{l|c|c|c|ccc}
\hline & \multicolumn{3}{|c}{$\begin{array}{c}\text { 'Allow many immigrants from poorer } \\
\text { countries outside Europe to come and } \\
\text { live here' }\end{array}$} & $\begin{array}{c}\text { 'Allow many immigrants of different } \\
\text { race/ethnic group to come and live here' }\end{array}$ \\
\hline & \multicolumn{7}{c}{$\%$ Minutes played by foreign players } \\
\hline & 30 & 50 & 70 & 30 & 40 & 70 \\
\hline Winner & $0.140^{* *}$ & $0.227^{* *}$ & $0.338^{* *}$ & $0.146^{* *}$ & $0.220^{* *}$ & $0.312^{* *}$ \\
& $(0.020)$ & $(0.144)$ & $(0.019)$ & $(0.024)$ & $(0.018)$ & $(0.022)$ \\
\hline No winner & $0.232^{* *}$ & $0.234^{* *}$ & $0.235^{* *}$ & $0.235^{* *}$ & $0.228^{* *}$ & $0.222^{* * *}$ \\
& $(0.008)$ & $(0.009)$ & $(0.020)$ & $(0.007)$ & $(0.010)$ & $(0.022)$ \\
\hline \multicolumn{7}{c}{$* * p<0.01$. In parentheses, the standard errors. }
\end{tabular}

\section{Conclusions}

Our results extend the literature on immigration framing

In conclusion, the main finding of the current research suggest that the regional attitudes toward inmigrantion may be modulate by the success of profesional clubs. Citizens have much more positive views toward inmigrants the more foreign players the winning teams has. Future research should verify the current results in other countries with different popular support for inmigration. Perhaps the Per Capita Income or the number of legal or ilegal inmigrants may affect the effect. Present results could be replicated with in other popular sports such as basketball, rugby or athletics. Future research should move from country/aggregated level to the player/individual one considering other variables such as the nationality of the players, their market value, the amount of money spend by clubs to sign a player, the playing position or the number of consecutive seasons played by a footballer in the club.

\section{References}

Abrajano, Marisa A, Zoltan Hajnal and Hans J.G Hassell (2017). "Media Framing and Partisan Identity: The Case of Immigration Coverage and White Macropartisanship." Journal of Race, Ethnicity and Politics 2: 5-34.

Binder, John J. and Murray Findlay (2012). "The Effects of the Bosman Ruling on National and Club Teams in Europe." Journal of Sports Economics 13: 107-129.

Brader, Brader, Nicholas A. Valentino and Elizabeth Suhay (2008). "What Triggers Public Opposition to Immigration? Anxiety, Group Cues, and Immigration Threat." American Journal of Political Science 52: 959-978.

Brambor, Thomas, William Roberts Clark and Matt Golder (2006). "Understanding Interaction Models: Improving Empirical Analyses." Political Analysis 14: 63-82.

Bryan, Mark L. and Stephen P. Jenkins (2016). "Multilevel Modelling of Country 
Effects: A Cautionary Tale.” European Sociological Review 32: 3-22.

Ceohanu, Alin M. and Xavier Escandell (2010). "Comparative Analyses of Public Attitudes Toward Immigrants and Immigration Using Multinational Survey Data: A Review of Theories and Research." Annual Review of Sociology 36: 309-328.

Chong, Dennis and James N. Druckman (2007). "Framing Theory." Annual Review of Political Science 10: 103-126.

Dunway, Johanna, Regina P. Branton and Marisa A. Abrajano (2010). “Agenda Setting, Public Opinion, and the Issue of Immigration Reform." Social Science Quarterly 91: 359-378.

Granda, Peter, Christof Wolf and Reto Hadordn (2010). "Harmonizing Survey Data". In Survey Methods in Multinational, Multiregional, and Multicultural Contexts, eds. Janet A. Harkness, Michael Braun, Brad Edwards, Timothy P. Johnson, Lars Lyberg, Peter Ph. Mohler, Beth-Ellen Pennell and Tom W. Smith. New Jersey: Wiley.

Hainmueller, Jens and Daniel J. Hopkins (2014). "Public Attitudes Toward Immigration.” Annual Review of Political Science 17: 225-249.

Jones, Bradford and Danielle Joesten Martin (2017). "Path Citizenship or Deportation? How Elite Cues Shaped Opinion on Immigration in the 2010 U.S. House Elections.” Political Behavior 39: 177-204.

Knoll, Benjamin R. and David P. Redlawsk (2011). "Framing Labels and Immigration Policy Attitudes in the Iowa Caucuses: "Trying to Our-Tancredo Tancredo." Political Behavior 33: 433-454.

Merolla, Jennifer, S. Karthick Ramakrishman and Chris Haynes (2013). “'Illegal,' 'Undocumented,' or 'Unauthorized': Equivalency Frames, Issue Frames, and Public Opinion on Immigration.” Perspectives on Politics 11: 789-807.

Nielsen Sports (2018). World Football Report 2018. The Nielsen Company.

Poli, Raffaele, Roger Besson and Loïc Ravenel (2017). World expatriate footballers. (No. 25). Neuchâtel: CIES.

Poli, Raffaele, Loïc Ravenel and Roger Besson (2018). Ten years of demographic analysis of football players' labor market in Europe. (No. 39). Neuchâtel: CIES.

Royuela, Vicente and Roberto Gásquez. (2018). "On the Influence of Foreign Players on the Success of Football Clubs." Journal of Sports Economics https://doi.org/10.1177/1527002518807960.

Zaller, John R. (1992). The nature and origins of mass opinion. Cambridge: Cambridge University Press. 